\title{
KARAKTERISTIK KOMITE AUDIT DALAM MEMENGARUHI TINDAKAN MANAJEMEN LABA (STUDI EMPIRIS PADA PERUSAHAAN MANUFAKTUR YANG TERDAFTAR DI BEI)
}

\author{
${ }^{1}$ Yosua Wage Supriyadi, ${ }^{2}$ Yoremia Lestari Ginting, ${ }^{3}$ Irwansyah \\ 1,2,3 Jurusan Akuntansi, Fakultas Ekonomi dan Bisnis, Universitas Mulawarman \\ yosua.wage.supriyadi15@mhs.feb.unmul.ac.id
}

\begin{abstract}
This study aims to examine how personal characteristics of audit committee members influence earnings management actions that occur within a company. This study uses a sample of consumer goods manufacturing sector companies listed on the Indonesia Stock Exchange (IDX) in the 2013-2017 periods, with a total of 129 data samples. The characteristics of the audit committee are proxied by the size of the audit committee, the number of independent audit committee members, the gender difference of the audit committee, the number of audit committee meetings and the background of the audit committee, while earnings management is proxied using accrual discretion values. The results of this study indicate that the size of the audit committee does not influence earnings management actions; independent audit committees can influence earnings management actions but with positive direction; the gender difference of the audit committee does not influence earnings management actions, the number of audit committee meetings does not influence earnings management actions; and only the background of the audit committee members that is likely to influence earnings management actions in a negative direction. This research provides a practical contribution in minimizing earnings management actions and conceptual contributions to the development of literature on earnings management at a later date.
\end{abstract}

Keywords: audit committee, earnings management, good corporate governance

\begin{abstract}
Abstrak: Penelitian ini bertujuan untuk menguji pengaruh karakteristik personal komite audit terhadap tindakan manajemen laba yang terjadi di dalam suatu perusahaan. Penelitian ini menggunakan sampel perusahaan industri manufaktur sektor barang konsumsi yang terdaftar di Bursa Efek Indonesia (BEI) periode 2013-2017 yang berjumlah 129 sampel data. Karakterisitk komite audit diproksikan dengan ukuran komite audit, jumlah anggota komite audit independen, perbedaan gender komite audit, jumlah pertemuan rapat komite audit dan latar belakang komite audit, sedangkan manajemen laba diproksikan menggunakan nilai diskresi akrual. Hasil dari penelitian ini menunjukkan bahwa ukuran komite audit tidak dapat memengaruhi tindakan manajemen laba, komite audit independen dapat memengaruhi tindakan manajemen laba namun dengan arah yang postif, perbedaan gender komite audit tidak dapat memengaruhi tindakan manajemen laba, jumlah rapat komite audit tidak dapat memengaruhi tindakan manajemen laba dan hanya latar belakang komite audit yang mampu memengaruhi tindakan manajemen laba dengan arah negatif. Penelitian ini dapat memberikan kontribusi praktis dalam meminimalisir tindakan manajemen laba dan kontribusi konseptual bagi pengembangan literatur tentang manajemen laba selanjutnya.
\end{abstract}

Kata Kunci: good corporate governance, komite audit, manajemen laba 


\section{Pendahuluan}

Sebuah informasi laba dapat menggiring para investor untuk menghentikan dan menarik kembali dana investasinya ketika laba yang dihasilkan tidak cukup menjanjikan kemakmuran atau bahkan merugi, informasi laba juga dapat membuat investor untuk mempertahankan investasinya atau bahkan menambah investasinya jika laba yang dihasilkan perusahaan mampu meningkatkan kemakmuran para pemegang saham. Maka laporan laba sudah seharusnya dapat menggambarkan kondisi kinerja perusahaan secara benar dan dapat diandalkan dalam pengambilan keputusan yang dibuat oleh manajer dan juga para investor.

Pada sebuah korporasi besar dengan kepemilikan terbuka, pada dasarnya antara pengelola dan pemilik perusahaan adalah orang yang berbeda. Lebih lanjut hal ini menimbulkan permasalahan konflik kepentingan yang terjadi karena adanya ketidakseimbangan informasi (Triyuwono, 2018) yang diperoleh para principal (pemilik) dibandingkan dengan agent (manajer). Sehingga dengan adanya asimetri informasi ini pemegang saham tidak tahu persis apa yang dilakukan manajer. Maka dari itu para agent akan lebih mendahulukan kepentingan pribadinya dibandingkan dengan kepentingan principal.

Sebagai informasi menjadi sebuah celah bagi manajer yang merasa ada kesempatan untuk melakukan tindakan diskresi akrual pada pos-pos tertentu dengan cara yang tidak lazim yang dapat menaikkan atau bahkan menurunkan laba namun tidak berdampak pada profitabilitas perusahaan dalam jangka panjang atau yang lebih dikenal dengan istilah manajemen laba. Untuk dapat mengatasi ketidakselarasan kepentingan dan ketidaksejajaran informasi, kemudian muncul konsep Tata Kelola Perusahaan yang Baik atau yang dikenal sebagai Good Corporate Governance (GCG). Asas-asas yang terdapat dalam GCG antara lain: transparansi, akuntabilitas, responsibilitas, independensi serta kewajaran dan kesetaraan yang diperlukan untuk mencapai kesinambungan usaha (sustainability) perusahaan dengan memperhatikan pemangku kepentingan (KNKG, 2006).

Agar GCG ini dapat terlaksana maka disusunlah sebuah mekanisme yang terdiri dari beberapa struktur kelembagaan yang dapat memastikan GCG dilaksanakan dengan baik, salah satu struktur kelembagaan tersebut adalah komite audit. Pada saat ini keberadaan komite audit telah diwajibkan oleh pemerintah bagi perusahaan yang listing di Bursa Efek Indonesia (BEI), agar dapat terlaksana dengan baik maka pemerintah mengeluarkan kebijakan melalui Keputusan Ketua Badan Pengawas Pasar Modal dan Lembaga Keuangan nomor: kep-643/BL/2012 tentang pembentukan dan pedoman pelaksanaan kerja komite audit, keputusan ini menyebutkan bahwa komite audit bertugas sebagai pengawas jalannya tata kelola perusahaan yang baik.

Tugas-tugas komite audit secara spesifik berbeda antara satu perusahaan dengan yang lainnya, namun secara garis besar tugas komite audit adalah untuk memastikan laporan keuangan disajikan secara wajar, memastikan audit internal berjalan dengan baik, melakukan pemilihan auditor eksternal secara independen dan mesatikan perusahaan mematuhi peraturan perundangan yang berlaku (KNKG, 2006) sehingga pemilihan dan pengangkatan seseorang menjadi komite audit adalah hal yang penting karena harus memperhatikan karakteristiknya.

Maka penelitian ini diharapkan mampu menjawab pertanyaan tentang pengaruh karakteristik komite audit yang diproksikan dengan ukuran komite audit, komite audit independen, perbedaan gender komite audit, jumlah pertemuan rapat komite audit dan latar belakang komite audit terhadap tindakan manajemen laba yang dilakukan oleh manajer pada perusahaan industri manufaktur sektor barang konsumsi.

Dalam penelitian ini karakterisik komite audit yang diproksikan dalam ukuran komite audit (UKA), komite audit independen (KAI), perbedaan gender komite audit (GKA), jumlah pertemuan rapat komite audit (PKA) dan latar belakang komite audit (LKA) berpengaruh terhadap manajemen laba (Ebrahim, 2011; Jati \& Sanjaya, 2011; Lin, Li, \& Yang, 2006; Prastiti \& Meiranto, 2013) namun berbeda hasil dengan penelitian lainnya yang menyatakan 
bahwa UKA, KAI, GKA, PKA dan LKA tidak berpengaruh terhadap manajemen laba (Mutiawero, 2014; Nugraha, 2014; Rahman, 2006).

Dari latar belakang yang ada dan beberapa penelitian sebelumnya yang memberikan hasil berbada dari pengaruh karaktersitik komite audit terhadap tindakan manajemen laba, penulis dalam penelitian bermaksud untuk menguji kembali pengaruh karakteristik komite audit tehadap manajemen laba dengan menggunakan perusahaan industri manufaktur sektor barang konsumsi sebagai objek penelitian dan memperbaharui tahun objek penelitan serta menambahkan variabel perbedaan gender komite audit untuk disatukan ke dalam model penelitian. Penelitian ini dapat memberikan kontribusi praktis dalam meminimalisir tindakan manajemen laba dan kontribusi konseptual bagi pengembangan literatur tentang manajemen laba selanjutnya.

\section{Kerangka Teoritis dan Pengembangan Hipotesis}

\subsection{Teori Keagenan}

Dalam Teori Keagenan yang dikemukakan oleh Jensen dan Meckling (1976) dijelaskan hubungan kontrak kerja antara prinsipal dan agen, dimana dalam hubungan kontrak tersebut pihak prinsipal sebagai pemilik sekaligus investor mendelegasikan tugas kepada agen untuk bertindak sesuai keinginan prinsipal.

Teori keagenan menghubungkan aspek perilaku manusia dalam teori ini di mana teori keagenan mengasumsikan bahwa baik pemilik modal (prinsipal) maupun pengelola (agen) adalah pihak yang rasional serta memiliki kepentingan masing-masing. Pihak yang rasional tentunya akan memaksimalkan kepentingan diri sendiri. Jika kedua belah pihak dalam hubungan tersebut adalah pemaksimal utilitas, ada alasan kuat untuk percaya bahwa agen tidak akan selalu bertindak demi kepentingan terbaik dari prinsipal (Jensen \& Meckling, 1976).

\subsection{Manajemen Laba}

Healy \& Wahlen (1998) mengungkapkan bahwa manajemen laba terjadi ketika manajer menggunakan pertimbangannya dalam menyusun laporan keuangan yang dapat membuat mislead para pemangku kepentingan mengenai kondisi mendasar yang ada dalam suatu perusahaan. Sedangkan manajemen laba menurut Scott (2015) adalah sebuah tindakan memilih metode akuntansi yang berpengaruh terhadap laba agar tercapainya angka laba tertentu secara spesifik.

\subsection{Ukuran Komite Audit}

Komite audit adalah pihak yang membantu dewan komisaris dalam rangka melaksanakan tugas dan fungsi dewan komisaris dalam hal kebijakan akuntansi perusahaan, pengawasan internal, dan sistem pelaporan keuangan (Siallagan \& Machfoedz, 2006). KNKG (2006) menjelaskan tugas-tugas Komite Audit antara lain memastikan bahwa:

1. Laporan keuangan disajikan secara wajar sesuai dengan prinsip akuntansi yang berlaku umum.

2. Perusahaan telah patuh dan taat terhadap peraturan perundang-undangan yang berhubungan dengan kegiatan perusahaan.

3. Struktur pengendalian internal perusahaan dilaksanakan dengan baik.

4. Pelaksanaan audit internal maupun eksternal dilaksanakan sesuai dengan standar audit yang berlaku.

5. Melakukan tindak lanjut temuan hasil audit yang dilaksanakan oleh manajemen.

Dalam kaitannya dengan manajemen laba, perusahaan yang memiliki komite audit seharusnya mampu meminimalisir tindak kecurangan yang dilakukan manajer melalui fungsi pengawasan terhadap sistem pelaporan keuangan. 
Marsha \& Ghozali (2017) menyatakan bahwa perusahaan yang memiliki jumlah anggota komite audit yang lebih banyak akan mengungkapkan manajemen laba yang lebih rendah. Berdasarkan uraian di atas, maka dirumuskan hipotesis sebagai berikut:

H1. Ukuran Komite Audit berpengaruh negatif terhadap Manajemen Laba.

\subsection{Komite Audit Independen}

FCGI (2002) menyebutkan bahwa Komite Audit agar beranggotakan Komite Independen ataupun dari eksternal perseroan, dan terlepas dari kegiatan manajemen sehari-hari dan mempunyai tanggung jawab utama untuk membantu Dewan Komisaris dalam menjalankan tanggung jawabnya. Komite audit harus independen artinya komite audit dalam menjalankan tugasnya harus bebas dari pengaruh apapun, tidak dikendalikan dan tidak memihak pada siapapun. Keberadaan komite audit independen bermanfaat untuk menjamin transparansi, keterbukaan laporan keuangan, keadilan untuk semua stakeholder, dan memastikan semua pengungkapan informasi telah dilakukan oleh manajemen meski ada konflik kepentingan.

Mutiawero (2014) menyatakan bahwa independensi komite audit memiliki hubungan negatif terhadap manajemen laba. Semakin independen anggota tersebut, maka kualitas pelaporan keuangan oleh perusahaan lebih dapat dipercaya. Berdasarkan uraian di atas, maka dirumuskan hipotesis sebagai berikut:

H2. Komite Audit Independen berpengaruh negatif terhadap manajemen laba.

\subsection{Perbedaan Gender Komite Audit}

Helgeson (2012) menjelaskan gender merupakan kategori sosial yang membedakan antara pria dan wanita berdasarkan penampilan psikologis dan sifat peran yang ditentukan oleh sosial. Pria dan wanita memiliki perbedaan dalam menyelesaiakan masalah, sedangkan Auditor wanita dipercaya cenderung lebih teliti dalam menemukan atau menyelesaikan suatu masalah dibandingkan dengan pria. Peni \& Vähämaa (2010) mengungkapkan bahwa pria dan wanita memiliki perbedaan dalam gaya kepemimpinan, kemampuan berkomunikasi, konservatisme, menghindari risiko, dan pembuatan keputusan.

Menurut penelitian Jati \& Sanjaya (2011) menunjukkan bahwa komite audit wanita berhubungan negatif dengan manajemen laba. Berdasarkan hasil penelitian terdahulu, maka dapat dirumuskan hipotesis sebagai berikut:

H3. Perbedaan Gender Komite Audit berpengaruh negatif terhadap Manajemen.

\subsection{Jumlah Rapat Komite Audit}

Rapat komite audit adalah forum bagi para komite audit untuk membahas rencana audit eksternal dan internal selama setahun serta rencana penyusunan laporan keuangan dan kepatuhan perseroan terhadap peraturan perundang-undangan. Dalam Keputusan Ketua BAPEPAM-LK Nomor: KEP-643/BL/2012 telah dijelaskan bahwa komite audit harus melakukan rapat minimal empat (4) kali dalam setahun. Diharapkan pertemuan rapat dengan frekuensi yang rutin maka mempermudah komite audit melakukan evaluasi, pengawasan dan pemilihan auditor eksternal yang berkompeten untuk meminimalisir adanya praktik manajemen laba.

Menurut penelitian yang telah dilakukan oleh Marsha \& Ghozali (2017) Jumlah pertemuan anggota komite audit yang lebih banyak akan mengungkapkan manajemen laba yang lebih rendah atau dengan kata lain keaktifan komite audit dapat mengurangi tingkat manajemen laba. Dari penjelasan di atas maka dapat dirumuskan hipotesis sebagai berikut:

H4. Jumlah Pertemuan Rapat Komite Audit berpengaruh negatif terhadap Manjemen Laba. 


\subsection{Latar Belakang Komite Audit}

Didalam putusan ketua BAPEPAM-LK nomor: KEP-643/BL/2012, komite audit wajib memahami laporan keuangan, bersedia meningkatkan kompetensi secara terus menerus dan wajib memiliki paling kurang satu anggota yang berlatar belakang pendidikan dan keahlian di bidang akuntansi. sehingga diharapkan latar belakang dan pengetahuan di bidang akuntansi serta keuangan memberikan dasar yang baik bagi anggota komite audit untuk memeriksa dan menganalisis informasi keuangan. Dalam kaitannya dengan praktik manajemen laba, komite audit yang berkompeten mampu memeriksa dan menganalisis informasi keuangan sehingga mampu mendeteksi adanya indikasi praktik manajemen laba.

Perusahaan yang memiliki komite audit dengan kompetensi yang besar dalam bidang keuangan atau akuntansi, cenderung memiliki kinerja dan pengawasan yang lebih baik kepada manajemen, sehingga manajemen laba dapat dihindari (Dwikusumowati \& Rahardjo, 2013). Dari penjelasan di atas dapat dirumuskan hipotesis sebagai berikut:

H5. Latar Belakang Komite Audit berpengaruh negatif terhadap Manajemen Laba.

\subsection{Model Penelitian}

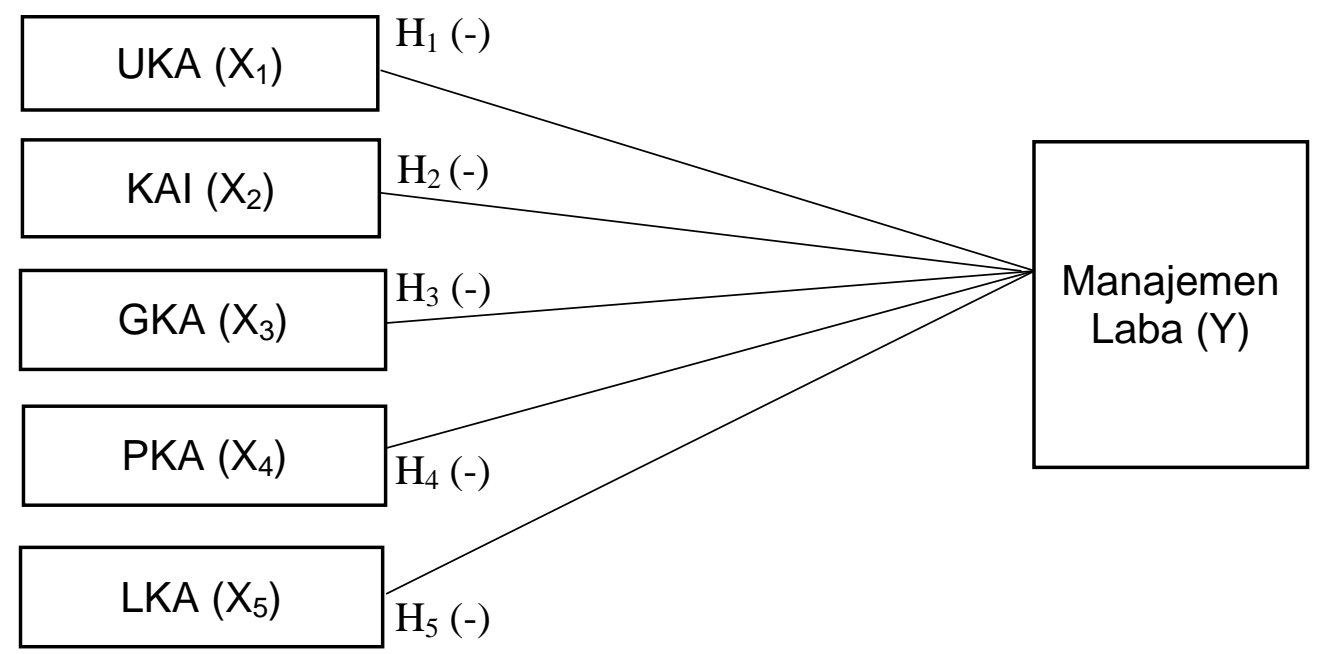

\section{Metode Penelitian}

\subsection{Sampel dan Pengumpulan Data}

Sampel dalam penelitian ini adalah perusahaan industri manufaktur sektor barang konsumsi yang terdaftar di Bursa Efek Indonesia (BEI) dengan kriteria bahwa perusahaan tersebut mebukukan laba dan memublikasikan laporan tahunan periode 2013-2017. Data dalam penelitian ini dikumpulkan dan diperoleh dari situs Indonesia Stock Exchange (IDX) serta dari situs resmi perusahaan.

\subsection{Metode Analisis Data}

\subsubsection{Analisis statistik deskriptif}

Analisis ini dilakukan untuk mengetahui gambaran deskriptif dari variabel-variabel yang diteliti, ditunjukkan dalam tabel deskriptif statistik yang di dalamnya menunjukkan angka minimum, maksimum, mean dan standar deviasi.

\subsubsection{Uji asumsi klasik}

Pengujian regresi dapat dilakukan setelah model dari penelitian ini memenuhi syarat yaitu lolos dari asumsi klasik. Syarat yang harus dipenuhi adalah data tersebut harus terdistribusikan secara normal, tidak mengandung multikolinearitas, dan heterokidastisitas. Hal ini dilakukan untuk menghindari terjadinya estimasi bias mengingat semua data tidak dapat diterapkan dalam regresi berganda. 


\subsubsection{Analisis regresi linear berganda}

Metode analisis yang digunakan penelitian ini adalah analisis regresi linear berganda. Berikut model persamaan regresi yang dikembangkan dalam penelitian ini:

DAit $=\alpha+\beta 1$ UKAit $+\beta 2$ KAIit $+\beta 3$ GKAit $+\beta 4$ PKAit $+\beta 5$ LKAit $+\mathrm{e}$

Keterangan:

DAit = discretionary accruals (proksi dari manajemen laba)

$\alpha \quad=$ konstanta

$\beta 1,2,3,4,5=$ koefisien regresi

UKAit $\quad=$ jumlah komite audit pada perusahaan $\mathrm{i}$ pada periode $\mathrm{t}$

KAIit $\quad=$ persentase komite audit independen pada perusahaan $\mathrm{i}$ pada periode $\mathrm{t}$

GKAit $\quad=$ keberadaan komite audit wanita pada perusahaan i pada periode $\mathrm{t}$

PKAit = jumlah pertemuan rapat komite audit pada perusahaan $\mathrm{i}$ pada periode $\mathrm{t}$

LKA $\quad=$ persentase komite audit yang memiliki keahlian keuangan pada perusahaan I pada periode $\mathrm{t}$

e $\quad=$ koefisien error

\subsubsection{Uji Kelayakan Model}

Uji kelayakan model dalam penelitian ini menggunakan Uji Statistik F yang dilakukan untuk mengukur ketepatan fungsi regresi sampel dalam menaksir nilai aktual secara statistik. Dasar pengambilan keputusan dalam uji ini adalah jika probabilitas (signifikansi) lebih besar dari 0.05 maka model penelitian tidak layak. Jika probabilitas lebih kecil dari 0.05 maka model penelitian dinyatakan layak.

\subsubsection{Uji Hipotesis}

Dalam penelitan ini uji hipotesis menggunakan Uji signifikan parameter individual (Uji Statistik t) untuk menguji seberapa jauh pengaruh satu variabel penjelas atau independen secara individual menerangkan variansi variabel dependen. Uji t tersebut dapat dilakukan dengan melihat nilai probabilitas signifikansi t masing-masing variabel yang terdapat pada output hasil regresi menggunakan SPSS. Jika nilai probabilitas signifikansi t lebih kecil dari 0,05 maka dapat dikatakan bahwa ada pengaruh yang kuat antara variabel independen dengan variabel dependen. Jika nilai probabilitas signifikansi t lebih besar dari 0,05 maka dapat dikatakan tidak ada pengaruh yang kuat antara variabel independen dengan variabel dependen.

\subsection{Variabel Dependen}

Variabel terikat yang digunakan dalam penelitian ini adalah manajemen laba yang diproksikan dengan discretionary accruals dan dihitung dengan model Jones yang dimodifikasi (Dechow, et al, 1995). Discretionary accrual dihitung dengan menggunakan rumus sebagai berikut:

$$
\text { TAC }=\text { Nit }- \text { CFOit }
$$

Nilai Total Accrual (TAC) yang diestimasi dengan persamaan regresi OLS (Ordinary Least Square) sebagai berikut:

$$
\text { TAit/Ait-1 }=\beta 1(1 / \text { Ait-1) }+\beta 2(\Delta \text { Revit/Ait-1) }+\beta 3(\text { PPEit/Ait-1 })+\mathrm{e}
$$

Menggunakan koefisien regresi tersebut, maka nilai non discretionary accruals (NDA) dapat dihitung dengan rumus:

$$
\text { NDAit }=\beta 1(1 / \text { Ait-1 })+\beta 2(\Delta \text { Revit/Ait-1 }-\Delta \text { Recit/Ait-1 })+\beta 3(\text { PPEit/Ait-1) }
$$


Selanjutnya Discretionary Accruals (DA) dapat dihitung sebagai berikut:

DAit = TAit/Ait-1 - NDAit

Keterangan:

DAit $=$ Discretionary Accruals perusahaan I pada periode ke $\mathrm{t}$

NDAit $\quad=$ Non Discretionary Accruals perusahaan I pada periode ke $\mathrm{t}$

TAit $=$ Total Akrual perusahaan i pada periode ke $\mathrm{t}$

Nit $\quad=$ Laba bersih perusahaan i pada periode ke $\mathrm{t}$

CFOit $\quad=$ Aliran kas dari aktivitas operasi perusahaan i pada periode ke $\mathrm{t}$

Ait-1 = Total aktiva perusahaan i pada periode ke $\mathrm{t}-1$

$\Delta$ Revit $\quad=$ Perubahan pendapatan perusahaan i pada periode ke $\mathrm{t}$

PPEit $\quad=$ Aktiva tetap perusahaan pada periode ke $\mathrm{t}$

$\Delta$ Recit $\quad=$ Perubahan piutang perusahaan i pada periode ke $\mathrm{t}$

e $\quad$ error

\subsection{Variabel Independen}

Variabel bebas dalam penelitian ini adalah karakteristik komite audit yang terdiri dari:

1. Ukuran komite audit

Indikator yang digunakan untuk mengukur komite audit dalam penelitian ini adalah seberapa banyak jumlah anggota komite audit yang ada dalam perusahaan secara numeral.

2. Komite audit independen

Indikator yang digunakan untuk mengukur komite audit independen dalam penelitian ini adalah persentase jumlah komite audit independen dari seluruh komite audit yang ada dalam perusahaan.

3. Perbendaan gender komite audit

Perbedaan gender komite audit diukur menggunakan variabel dummy yaitu berdasarkan ada tidaknya anggota komite audit wanita, angka satu (1) untuk keberadaan anggota komite audit wanita dan angka nol (0) tidak terdapat anggota komite audit wanita.

4. Jumlah rapat komite audit

Variabel ini diukur secara numeral, yaitu dilihat dari berapa banyak jumlah rapat yang dilakukan oleh komite audit selama satu tahun.

5. Latar belakang komite audit

Latar belakang komite audit diukur dengan jumlah presentasi anggota KA yang memliki latar belakang pendidikan akuntansi dan pengalaman dalam bidang keuangan dengan cara melihat satu pesatu profil KA yang terdapat dalam laporan tahunan perusahaan.

\section{Hasil Penelitian dan Pembahasan}

Populasi dalam penelitian ini adalah perusahaan industri manufaktur sektor barang konsumsi yang terdaftar di bursa efek Indonesia periode 2013-2017. Berdasarkan hasil seleksi kriteria yang telah dilakukan, diperoleh sebanyak 129 data yang telah terpilih dan memenuhi kriteria seperti yang terdapat dalam tabel di bawah ini.

Tabel 1. Purposive Sampling

\begin{tabular}{|l|l|c|c|c|c|c|}
\hline No & \multicolumn{1}{|c|}{ Kriteria } & 2013 & 2014 & 2015 & 2016 & 2017 \\
\hline 1 & Perusahaan manufaktur sektor barang konsumsi. & 38 & 39 & 40 & 40 & 47 \\
\hline 2 & Perusahaan yang tidak memublikasikan laporan tahunan. & $(8)$ & $(8)$ & $(10)$ & $(8)$ & $(14)$ \\
\hline 3 & \begin{tabular}{l} 
Perusahaan yang membukukan kerugian. \\
\multicolumn{1}{|c|}{ Jumlah }
\end{tabular} & $(3)$ & $(2)$ & $(2)$ & $(3)$ & $(6)$ \\
\hline 4 & $\begin{array}{l}\text { Laporan tahunan perusahaan yang tidak terdapat informasi } \\
\text { mengenai komite audit. }\end{array}$ & 25 & 26 & 27 & 27 & 24 \\
\hline
\end{tabular}

Sumber: Data diolah (2019) 


\subsection{Statistik Deskriptif}

Deskripsi tentang sampel dalam bentuk maximum, minimum, mean, dan standar deviasi dapat dilihat melalui tabel di bawah ini.

Tabel 2. Statistik Deskriptif

\begin{tabular}{|l|r|r|r|r|r|}
\hline & $\mathrm{N}$ & Minimum & Maximum & \multicolumn{1}{c|}{ Mean } & \multicolumn{1}{c|}{ Std. Deviation } \\
\hline ManajemenLaba & 129 & -.11740 & .44842 & .1328869 & .10255521 \\
UkuranKomite & 129 & 2.00 & 5.00 & 3.1231 & .39405 \\
KomiteIndependen & 129 & 1.00 & 4.00 & .6520 & .12735 \\
PerbedaanGender & 129 & .00 & 1.00 & .4538 & .49979 \\
JumlahRapat & 129 & 2.00 & 30.00 & 6.3385 & 4.20327 \\
LatarBelakang & 129 & 1.00 & 4.00 & .7014 & .24003 \\
Valid N (listwise) & 129 & & & & \\
\hline
\end{tabular}

Sumber:Data diolah (2019)

Berdasarkan tabel di atas data dalam penelitian ini berjumlah 129. Nilai manajemen laba berada pada rentang -0,1174 sampai 0,4484 mengindikasikan bahwa perusahaan sampel melakukan income minimization dan income maximization, kemudian komite audit paling banyak beranggotakan 5 orang, jumlah tertinggi komite audit independen adalah 4 , sebanyak 59 komite audit terdapat keberadaan wanita, jumlah rapat terbanyak adalah 30 kali dan terendah adalah 2 kali rapat yang berarti masih ada komite audit yang tidak sesuai dengan peraturan tentang jumlah minimal rapat. dan jumlah tertinggi anggota komite audit yang memiliki latar belakang dan kemampuan akuntansi adalah 4 anggota.

\subsection{Uji Asumsi Klasik}

\subsubsection{Uji Normalitas}

Dalam penelitian ini uji normalitas menggunakan uji Kolmogrov Smirnov, berdasarkan hasilnya diketahui bahwa nilai signifikan Asiymp.Sig (2-tailed) sebesar 0,200 lebih besar dari 0,05. Maka dapat disimpulakn bahwa data berdistribusi normal.

\subsubsection{Uji Multikolinearitas}

Dasar pengambilan keputusan Uji Multikolinearitas dalam penelitian berdasarkan nilai Tolerance yang ada di tabel Collinearity Statistics yang diketahui nilai Tolerance untuk masing-masing variabel seluruhnya lebih besar dari 0,10. Maka dapat disimpulkan bahwa tidak terjadi gejala multikolinearitas pada model regresi.

\subsubsection{Uji Heteroskedastisitas}

Dasar pengambilan keputusan Uji Heteroskedastisitas dalam penelitian ini adalah dengan cara melihat hasil dari scatterplots yang diketahui bahwa data dalam penelitian ini menyebar di sekitar angka 0, tidak mengumpul hanya diatas atau dibawah saja, penyebaran titik tidak membentuk pola bergelombang, dan penyebaran titik-titik data tidak berpola. Sehingga dapat ditarik kesimpulan bahwa tidak terdapat gejala heteroskedastisitas, sehingga model regresi dapat terpenuhi.

\subsection{Analisis Regresi Linier Berganda}

Berdasrkan hasil uji F, model dalam penelitan ini dikatakan layak dan tidak terdapat variabel yang dikeluarkan dari model penelitan. Sehingga analisis regresi linier berganda dalam penelitian ini dapat dilihat dalam persamaan di bawah ini:

$$
\mathrm{DA}_{\text {it }}=-\mathbf{0 . 0 5 3}+0.002 \mathrm{UKA}_{\mathrm{it}}+0.192 \mathrm{KAI}_{\mathrm{it}}+0.112 \mathrm{GKA}_{\mathrm{it}}-0.024 \mathrm{PKA}_{\mathrm{it}}-0.312 \mathrm{LKA}_{\mathrm{it}}+\mathrm{e}
$$




\subsection{Kelayakan Model.}

Dari tabel 3 di bawah terlihat bahwa nilai signifikan hasil output Anova adalah $0.012<$ dari 0.05 yang berarti bahwa model regresi telah tepat dalam mengukur nilai aktual statistik dan model regresi dikatakan layak.

Tabel 3. Hasil Uji F

\begin{tabular}{|ll|r|r|r|r|c|}
\hline Model & & Sum of Squares & Df & Mean Square & F & \multicolumn{1}{c|}{ Sig. } \\
\hline 1 & Regression & 14.430 & 5 & 2.886 & 3.054 & $.012^{\mathrm{b}}$ \\
& Residual & 116.239 & 123 & .945 & & \\
& Total & 130.669 & 128 & & & \\
\hline
\end{tabular}

Sumber: Data diolah (2019)

\subsection{Uji Hipotesis}

Tabel 4. Hasil Uji t

\begin{tabular}{|c|c|c|c|c|c|c|}
\hline \multirow{2}{*}{\multicolumn{2}{|c|}{ Model }} & \multicolumn{2}{|c|}{ Unstandardized Coefficients } & \multirow{2}{*}{$\begin{array}{c}\text { Standardized } \\
\text { Coefficients } \\
\text { Beta } \\
\end{array}$} & \multirow[b]{2}{*}{$\mathrm{T}$} & \multirow[b]{2}{*}{ Sig. } \\
\hline & & $\mathrm{B}$ & Std. Error & & & \\
\hline 1 & (Constant) & -.053 & .086 & & -.618 & .538 \\
\hline & Ukuran Komite & .002 & .089 & .002 & .024 & 981 \\
\hline & Komite Independen & .192 & .091 & 199 & 2.105 & 037 \\
\hline & Perbedaan Gender & .112 & .098 & .110 & 1.144 & 255 \\
\hline & Jumlah Rapat & -.024 & .095 & -.024 & -.254 & 800 \\
\hline & Latar Belakang & -.312 & .098 & -.310 & -3.185 & .002 \\
\hline
\end{tabular}

Sumber: Data diolahh (2019)

Berikut akan diuraikan penjelasan mengenai hasil pengolahan data yang telah dilakukan dan pengambilan keputusan hipotesis :

\subsubsection{Pengaruh Ukuran Komite Audit terhadap Manajemen Laba.}

Berdasarkan hasil penelitian, menunjukkan bahwa variabel ukuran komite audit memiliki nilai koefisien regresi 0.002 dengan nilai signifikansi 0.981 . Hal ini berarti hipotesis pertama ditolak karena probabilitasnya sebesar 0.981 tidak signifikan pada 0,05 dan memiliki arah positif, sehingga dapat diprediksikan bahwa ukuran komite audit tidak dapat memngaruhi tindakan manajemen laba.

Hal ini terjadi karena komite audit hanya badan yang memberikan saran dan pengawasan terhadap pelaporan keuangan perusahaan agar tetap wajar dalam konteks standar akuntansi, namun kita ketahui bahwa terdapat berbagai metode pengukuran akuntansi yang menjadi kewenangan manajer dalam menyusun laporan keuangan, yang tentu saja dapat disalahgunakan untuk melakukan memanajemen laba. Dengan kata lain, besar kecilnya ukuran komite audit tidak akan bisa memberikan pengaruh terhadap keputusan yang diambil oleh manajer dalam pemilihan metode penyusunan laporan keuangan. Hasil ini sesuai dengan penelitian yang dilakukan oleh Putri (2011) yang menunjukkan pengaruh yang tidak terlalu signifikan anatar ukuran komite audit dan manajemen laba.

\subsubsection{Pengaruh Komite Audit Independen terhadap Manajemen Laba.}

Berdasarkan hasil penelitian, menunjukan bahwa variabel komite audit independen memiliki nilai koefisien regresi 0.192 dengan nilai signifikansi 0.037 lebih kecil dari 0,05 atau dapat dikatakan hasil signifikan. maka dapat disimpulkan bahwa hipotesis kedua ditolak walaupun menunjukan pengaruh yang kuat namun memiliki arah postif.

Hasil ini menunjukan bahwa semakin banyak anggota independen dari komite audit akan meningkatkan manajemen laba. Peneliti berpendapat bahwa dengan tingkat manajemen laba yang tinggi akan dibutuhkan lebih banyak komite audit independen didalam perusahaan 
untuk dapat melakukan mitigasi tindak kecurangan tersebut, sehingga diharapkan di periode berikutnya tingkat manajemen laba akan menurun. Hasil ini sejalan dengan penelitian yang dilakukan oleh Aji (2012) yang menyatakan independensi komite audit memberikan pengaruh yang signifikan terhadap terjadinya manajemen laba.

\subsubsection{Pengaruh Perbedaan Gender Komite Audit terhadap Manajemen Laba.}

Berdasarkan hasil penelitian, menunjukan bahwa variabel komite audit independen memiliki nilai koefisien regresi 0.112 dengan nilai signifikansi 0.255 lebih besar dari 0,05 atau dapat dikatakan tidak signifikan. maka dapat disimpulkan bahwa hipotesis ketiga ditolak karena menunjukan pengaruh yang lemah dan memiliki arah postif.

Hasil ini menunjukan perbedaan gender didalam komite audit tidak dapat memengaruhi manajemen laba, hal ini terjadi karena gender dalam penelitian ini yang merujuk pada keberadaan wanita belum memiliki kesetaraan dengan pria, ini juga berhubungan dengan keadaan sosial di Indonesia yang belum terlalu menjunjung tinggi kesetaraan gender. Hasil ini sejalan dengan peneltian Novilia dan Nugroho (2016), berdasarkan hasil pengujian mereka bahwa komite audit wanita berpengaruh positif namun tidak signifikan terhadap manajemen laba.

\subsubsection{Pengaruh Jumlah Rapat Komite Audit terhadap Manajemen Laba.}

Berdasarkan hasil penelitian, menunjukan bahwa variabel jumlah rapat komite audit memiliki nilai koefesien regresi -0,024 dan signifikansi 0.800 lebih besar dari 0,05 atau dapat dikatakan tidak signifikan. Maka dapat disimpulkan bahwa hipotesis keempat ditolak karena pengaruh yang lemah terhadap manajemen laba.

Jika dilihat dalam tabel statistik deskriptif nampak bahwa jumlah rapat yang dilakukan komite audit rata-rata berjumlah enam kali rapat dan jumlah rapat terbanyak adalah 30 kali yang mana melebihi aturan yang telah ditetapkan BAPEPAM, yaitu berjumlah empat kali rapat dalam setahun. Hal ini bisa saja membuat pertemuan rapat yang dilakukan komite audit kurang efektif sehingga tidak dapat memengarhui tindakan manajemen laba. Hasil ini sejalan dengan penelitian yang telah dilakukan oleh Saleh et al., (2007) diperoleh hasil bahwa frekuensi pertemuan yang dilakukan oleh komite audit memiliki hubungan positif dan tidak signifikan dengan manajemen laba.

\subsubsection{Pengaruh Latar Belakang Komite Audit terhadap Manajemen Laba.}

Berdasarkan hasil penelitian, menunjukan bahwa variabel latar belakang komite audit memiliki koefesien regresi $-0,312$ dan nilai signifikansi 0.002 lebih kecil dari 0,05 atau dapat diakatakan signifikan. Maka dapat disimpulkan bahwa hipotesis kelima diterima karena memliki pengaruh yang kuat dan dengan arah negatif.

Dengan anggota komite audit yang profesional dan menguasai bidangnya dapat dipastikan saran dan masukan strategis yang diberikan adalah yang terbaik dan sesuai dengan standar akuntansi yang ada. Hal ini lebih lanjut lagi dapat berdampak pada kewajaran laporan keuangan yang telah disampaikan kepada pihak yang berkepentingan. Hasil ini sejalan dengan penelitian Dwikusumowati dan Rahardjo (2013) yang menunjukkan bahwa perusahaan yang memiliki komite audit dengan kompetensi yang besar dalam bidang keuangan atau akuntansi cenderung memiliki kinerja dan pengawasan yang lebih baik kepada manajemen, sehingga manajemen laba dapat dihindari. 


\section{Kesimpulan dan Keterbatasan Penelitian}

\subsection{Kesimpulan}

Berdasarkan hasil dan pembahasan pada bagian sebelumnya peneliti menyimpulkan bahwa:

1. Ukuran Komite Audit tidak dapat memengaruhi tindakan Manajemen Laba. Besar maupun kecil ukuran komite audit sebuah perusahaan diprediksi tidak memberikan dampak terhadap terjadinya manajemen laba.

2. Komite Audit Independen dapat memengaruhi tindakan manajemen laba namun dengan arah yang positif, artinya bahwa semakin banyak jumlah anggota komite audit independen didalam sebuah perusahaan akan meningkatkan tindakan manajemen laba.

3. Perbedaan Gender Komite Audit tidak dapat memengaruhi tindakan manajemen laba. Hal ini berarti bahwa perbedaan gender atau bahkan keseragaman gender yang ada didalam komite audit sebuah perusahaan diprediksi tidak memberikan pengaruh terhadap terjadinya tindakan manajemen laba.

4. Jumlah Rapat Komite audit tidak dapat memengaruhi tindakan Manajemen Laba. Seberapa sering komite audit melaksanakan rapat intern, diprediksi tidak dapat memengaruhi terjadinya manajemen laba.

5. Latar Belakang Komite Audit mampu memengaruhi tindakan manajemen laba dengan arah negatif. artinya bahwa semakin banyak komite audit yang memiliki latar belakang pendidikan akuntansi dan pengalaman dalam bidang keuangan diprediksi akan mampu menurunkan tindakan manajemen laba.

\subsection{Keterbatasan Penelitian}

Keterbatasan dalam penelitian ini adalah: 1) populasi dalam penelitian ini terbatas pada perusahaan industri manufaktur sektor barang konsumsi. 2) terbatasnya informasi tentang komite audit yang tersedia didalam laporan tahunan. 3) tidak semua perusahaan memublikasikan laporan tahunan selama periode 2013-2017 dengan lengkap pada website perusahaan.

\subsection{Saran}

Diharapkan penelitian kedepannya untuk dapat menggunakan variabel di luar karakteristik komite audit, seperti komite nominasi dan remunerasi, komite good corporate governance dan dewan komisaris dalam usaha pembuktian empris mekanisme GCG dalam mengurangi tindakan manajemen laba.

Berdasarkan hasil penelitian terdapat beberapa variabel independen yang tidak berpengaruh signifikan dan juga terdapat variabel yang keberadaanya meningkatkan manajemen laba. Sehingga peneliti berasumsi bahwa tugas dan tanggung jawab komite audit belum berjalan dengan baik. Maka dari itu diharapkan bagi emiten BEI untuk dapat menjadikan komite audit tidak hanya sebagai pemenuhan syarat untuk dapat melakukan penawaran saham perdana pada BEI, namun juga harus menghormati keberadaan dan legitimasi komite audit. 


\section{Daftar Pustaka}

Aji, Aditya Bayuputranto. 2012. Analisis Pengaruh Karakteristik Komite Audit Terhadap Kualitas Laba Dan Manajemen Laba Di Bursa Efek Indonesia. Skripsi tidak diterbitkan. Semarang: Fakultas Ekonomi dan Bisnis Universitas Diponegoro.

Dechow, P. M., Sloan, R. G., \& Sweeney, A. P. (1995). Detecting Earnings Management. The Accounting Review, 70(2), 193-225.

Dwikusumowati, M. Z., \& Rahardjo, S. N. (2013). Pengaruh Karakteristik Komite Audit Dan Karakteristik Perusahaan Terhadap Manajemen Laba. Diponegoro Journal of Accounting, 2(4), 1-14.

Ebrahim, A. (2011). Earnings management and board activity: an additional evidence", Review of Accounting and Finance, Vol. 6 Iss 1 pp. 42 - 58 http://dx.doi.org/10.1108/14757700710725458

FCGI. (2002). Peranan Dewan Komisaris dan Komite Audit dalam Pelaksanaa Corporate Governance ( Tata Kelola Perusahaan ).

Healy, P. M., \& Wahlen, J. M. (1998). A Review Of The Earnings Management Literature And Its Implications For Standard Setting. Bloomington, Boston

Helgeson, V. S. (2012). The psychology of gender.(4th ed.). New Jersey: Pearson Education, Inc

Indonesia, I. K. A. (2004). IKAI. Diakses February 5, 2019, from http://www.komiteaudit.or.id/tentang-komiteaudit/

Jati, A. Y. M., \& Sanjaya, I. P. S. (2011). Pengaruh Karakteristik Personal Komite Audit terhadap Real Earnings Management, Universitas Atmajaya Yogyakarta.

Jensen, M. C., \& Meckling, W. H. (1976). Theory of the Firm: Managerial Behavior , Agency Costs and Ownership Structure Theory of the Firm: Managerial Behavior, Agency Costs and Ownership Structure. Journal of Financial Economic, 3, 305-360.

KNKG. (2006). Pedoman Umum GCG Indonesia. Indonesia. Retrieved from http://www.ecgi.org/codes/documents/indonesia_cg_2006_id.pdf

Lin, J. W., Li, J. F., \& Yang, J. S. (2006). The effect of audit committee performance on earnings quality, 21(9), 921-933. https://doi.org/10.1108/02686900610705019

Marsha, F., \& Ghozali, I. (2017). Pengaruh Ukuran Komite Audit, Audit Eksternal, Jumlah Rapat Komite Audit, Jumlah Rapat Dewan Komisaris, dan Kepemilikan Institusional Terhadap Manajemen Laba (Studi Empiris Perusahaan Manufaktur yang Terdaftar di BEI Tahun 2012-2014). Diponegoro Journal of Economics, 6(2), 1-12. https://doi.org/2337-3814

Mutiawero, M. (2014). "Pengaruh Komite Audit Terhadap Manajemen Laba (Studi Pada Industri Manufaktur yang Terdaftar di BEI)". Skripsi Fakultas Ekonomi dan Bisnis, Universitas Hasanuddin Makasar.

Nugraha, N. F. (2014). "Pengaruh Reputasi Auditor Dan Karakteristik Komite Audit Terhadap Manajemen Laba" Skripsi Program Studi Akuntansi, Fakultas Ekonomi dan Bisnis. Universitas Muhamadiah Yogyakarta.

Novila, O., \& Nugroho, P. I. "Pengaruh Manajemen Puncak Wanita Terhadap Manajemen Laba" Dinamika Akuntansi, Keuangan dan Perbankan, Mei 2016, Hal: 27- 45 Vol. 5, No. 1 ISSN :1979-4878

Peni, E., \& Vähämaa, S. (2010). Female executives and earnings management. Managerial Finance, 36(7), 629-645. https://doi.org/10.1108/03074351011050343

Prastiti, A., \& Meiranto, W. (2013). Pengaruh Karakteristik Dewan Komisaris Dan Ukuran Perusahaan Terhadap Manajemen Laba. Diponegoro Journal of Accounting, 2(4), 1-12. 
Pemerintah Republik Indonesia. 2012. Keputusan Ketua Badan Pengawas Pasar Modal dan Lembaga Keuangan nomor: kep-643/BL/2012 tentang pembentukan dan pedoman pelaksanaan kerja komite audit.Jakarta: Badan Pengawas Pasar Modal dan Lembaga Keuangan.

Putri, Destika Maharani. 2011. Pengaruh Karakteristik Komite Audit TerhadapManajemen Laba (Studi Empiris pada Perusahaan Manufaktur yangTerdaftar di Bursa Efek Indonesia Periode Tahun 2007-2009). Skripsi tidak diterbitkan. Semarang: Fakultas Ekonomi Universitas Diponegoro.

Rahman, R. A. (2006). Board, audit committee, culture and earnings management: Malaysian evidence. Managerial Auditing Journal, 21(7), 783-804. https://doi.org/10.1108/02686900610680549

Saleh, N. I. (2007). "Audit committee characteristics and earnings management:evidence from Malaysia. Asian Review of Accounting", Vol. 15 No. 2, 147163.

Scott, W. R. (2015). Financial Accounting Theory $7^{\text {th }}$ ed. Person Education Canada. inc

Siallagan, H., \& Machfoedz, M. (2006). Mekanisme Corporate Governance, Kualitas Laba dan Nilai Perusahaan. Simposium Nasional Akuntansi IX, (061), 1-23.

Triyuwono, E. (2018). Proses Kontrak, Teori Agensi dan Corporate Governance. Universitas Atmajaya Makassar. Diakses 23 Februari 2019. https://www.researchgate.net/publication/322487689 